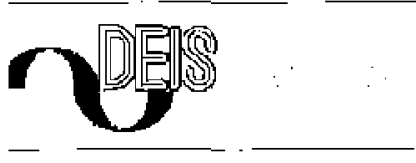

\title{
Advanced Partial Discharge Diagnostic of MV Power Cable System Using Oscillating Wave Test System
}

Key Words: Discharging faults, predictive maintenance, fault location, cable insulation, cable accessories

$\mathrm{M}$ edium-voltage cables are of key importance in the powel distribution network. 'The enormous lengths of cable now installed, together with the socioconomic costs of failure, have identified MV calble networks as a target for further attention.

Quality-assured components have been assembled together in a medium-voltage supply network which, if it fails, will cause repair costs, customer complain's, and loss of revenue or cven associated chins. In fact, many sections of the network are frequently very mature, consisting of carlicr rypes of components such as paper oil cables and bitumen joints. Mixtures of component types, ages, and workmanship standards resule in a network whose reliability is difficult to predict. The modern trend is for asset managers in electrical utility companies to instigate predictive maintenance prograns in an attempt to repair potentially faulty network components before problens occur. Of course, such a program nust show a cost benefit.

The detection, location, and recognition of partial discharges (PD) at an carly stage of possible insulation failure in medium voltnge are of great importance for mantenance purposes. As a result, maintenance actions can be planned mote precisely to prevent mexpected discontinutics in operation of the calle network (Fig. 1).

'To obtatu a sensitive picture of discharging fauls in power cables the l'1) should be ignited, detected, and located at power frequencies that are cotmparable to operating conditions at 50 or $60 \mathrm{H} \%$. In this way, roalistic magnitudes in $[\mathrm{pC}]$ and reproducible patterus of discharges in a power cable cal be obtained. 'P measurements during service as well as on-site conlinuous energizing at $50(60) \mathrm{H} z$ of MV cables are not always economically realistic for on-site inspections. Different energizing methods have been introduced and enployed during recent years $[3-4,6]$. Therefort, based on the assumption that sensitive derection of critical $P D$ sites occurs
Edward Gulski, Frank J. Wester, and Johan J. Smit

Delft Universily of Tecbnology

Paul N. Seitz

Seitz Insimments $A G$

\section{Mark Turner}

Heafely Test AG, 'Tenex Instruments Division.

\section{The enormous lengths of cable now installed, together with the socioeconomic costs of failure, have identified $M V$ cable networks as a target for further attention.}

by a method most similar to $50 \mathrm{H} z$ cnergizing conditions, a method as introduced in $[4,6,7]$ for on-site PD diagnosis of MV cables witl be discussed (Fig, 2).

\section{Oscillating Wave Test System (OWTS) \\ Basic Theory of ascillating Waves}

With this method, the calse sample is charged with a $D C$ power supply over a period of just a few seconds to the usual service voltage (Fig. 4). Then a specially designed solid state switch connects an air-core inductor to the cable sample in al clostre time of $<1 \mu$ s (Fig. 3). Now series of voltage-cycles starl' oscillating with the resonant frequency of the circuit:

$$
F=1 /(2 \pi * \sqrt{ } \cdot * \mathrm{C})
$$




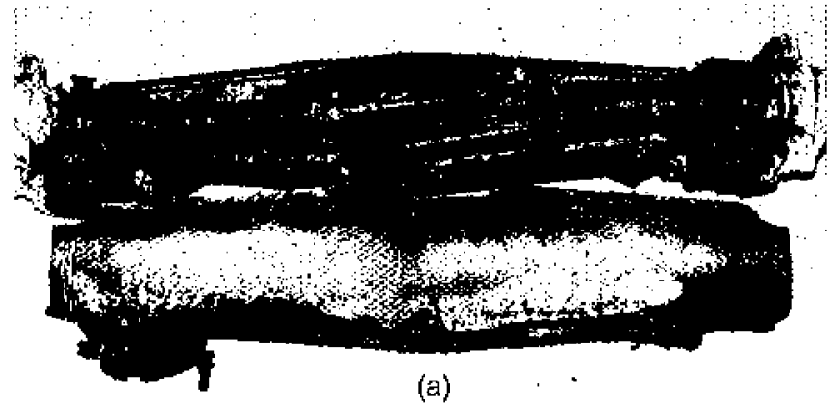

(a)

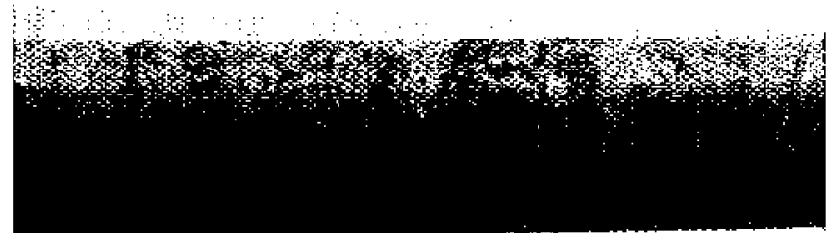

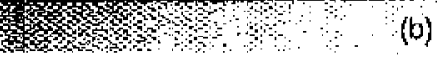
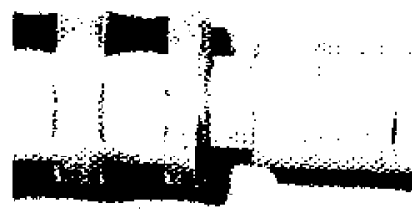

IHIH!n!

(c)

Figr. 1 Sixamples of defects, inswation degradation, and athes possible in a nediun-uollage cablo system:

a) exploded oil-filled cable joint, date to water entering in the joint as three-phase short circuit occurred

b) treeing in the insulation of at $45-y e a-o l d .50 \mathrm{kV}$ mass-innprentated polwer cable

c) mounting defect in a cable joint for piastic-insulated $10 \mathrm{kV}$ cable: carbon tracks after not properly removed semicon

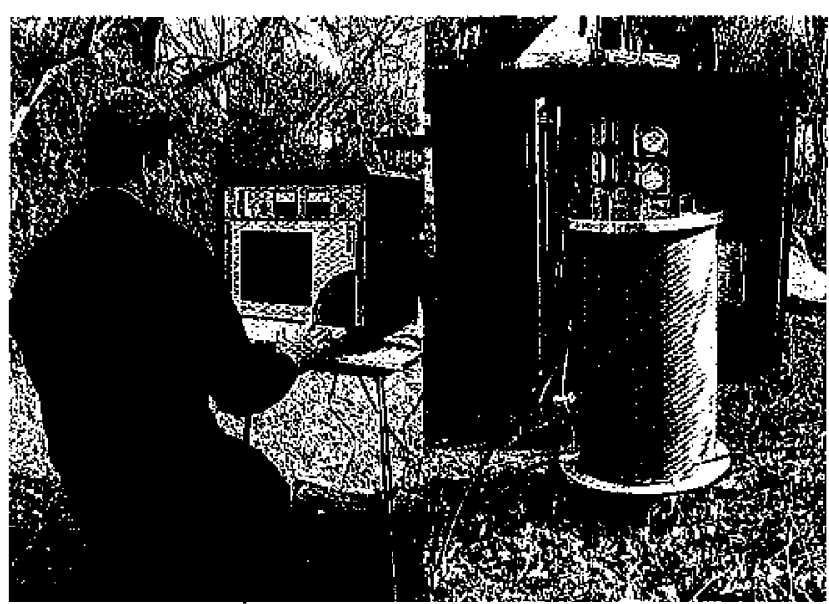

Wig. 2 Ligineer performing cabte measwrenents in the field

where $L$ represents the fixed inductance of the air cote and $C$ tepresents the capacitance of the cable sample (Fig. 5).

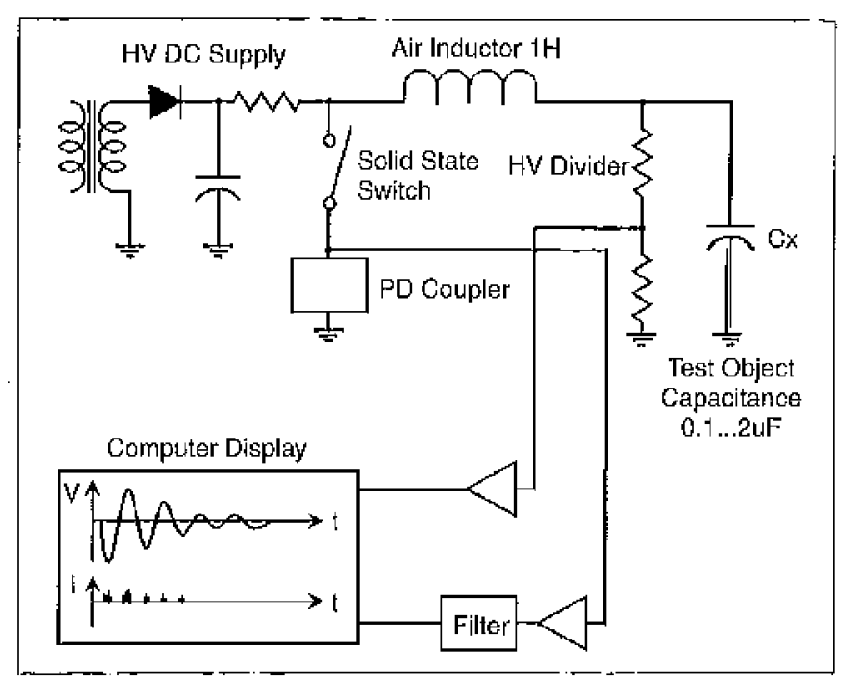

lig. 3 Schemaht diagram of the OWTS measwing circuit for on-site $P D$ detection and location in power cables $(<50 \mathrm{kV})$

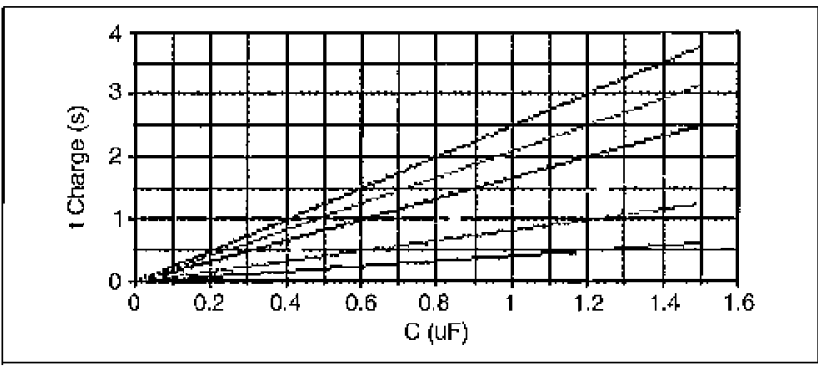

Fig. 4 Charging times neaded to obarge difform calle somples capat tancas to a spocific voltage lovel in (kVI (top down $30,25,20,15,10,5)$

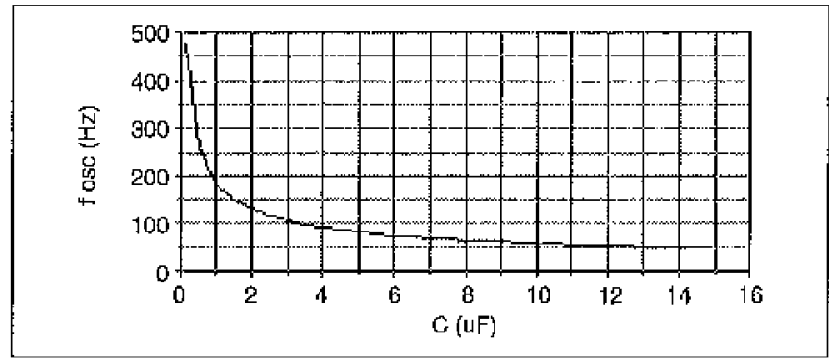

Hig. 5 Oscillating wave frequency as function of the cable capacitance

I'be air core inductor has a low loss factor and design, so that the resonant frequency lies close to the range of power ftequency of the service voltage: $50 \mathrm{~Hz}$ to $1 \mathrm{kHz}$. Due to the fact that the insulation of power cables usmally has a relative low dissipation factor, the $\mathrm{Q}$ of the resonant circuit remains high depending upon cable: 30 to more than 100 (Fig. 6). As a result, a slowly decaying oscillating waveform (decay time 0.3 to 1 second) of test voltage is applied to encrgize the cabie sample. During tens of power frequency cycles the PD signals are initiated in a way similar to $50(60) \mathrm{H}-\mathrm{Iz}$ inception conditions, All of these PD pulses are measured using a last digitizer. 


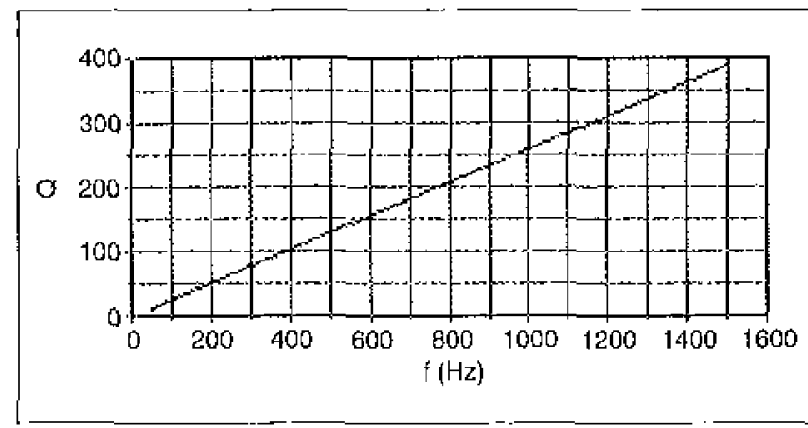

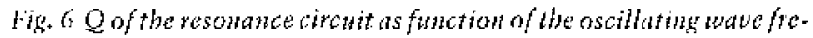
altency

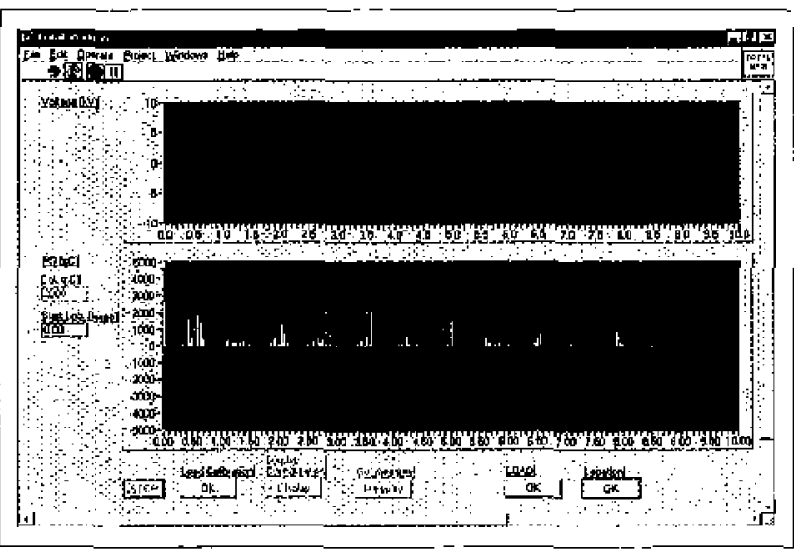

Fig. 7 Example of PD pulses as measured during $12 \mathrm{kV}$ oscillating wave on a $10 \mathrm{kV}$ XI.PF power cable, bawing internal discbatges

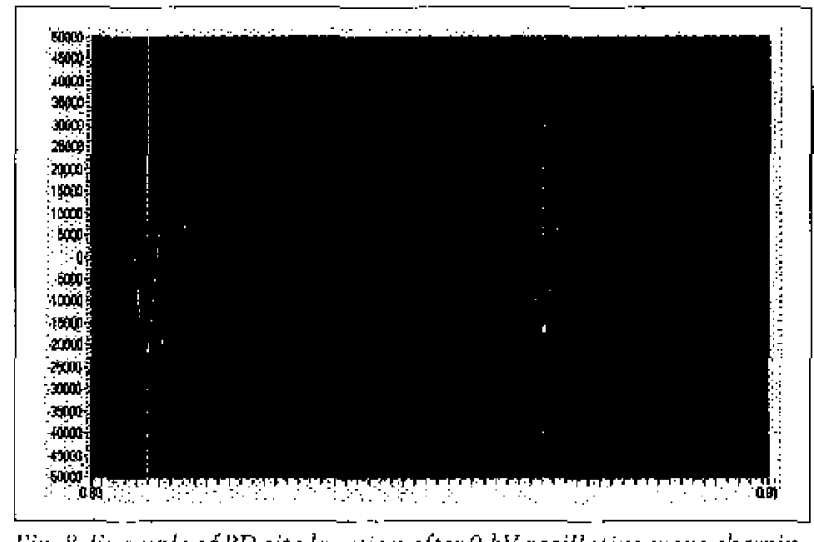

Fig. 8 lixample of lW site location after 9 kVoscillatirg thate cbargints of a $10 \mathrm{kV}$ paper-oil power cablo

\section{PD Detection}

The advantage of a high Q circuit is that PD can be measured on-site for a series of undisturbed sinusoidal cycles of the test voltage. for this purpose a special PD detection circuit has been used providing sensitive detection of discharge signals. Due to the fact that the switched DC power supply produces disturbances during clarging of the cable sample, the PD circuit is therefote inhitited during this time. During

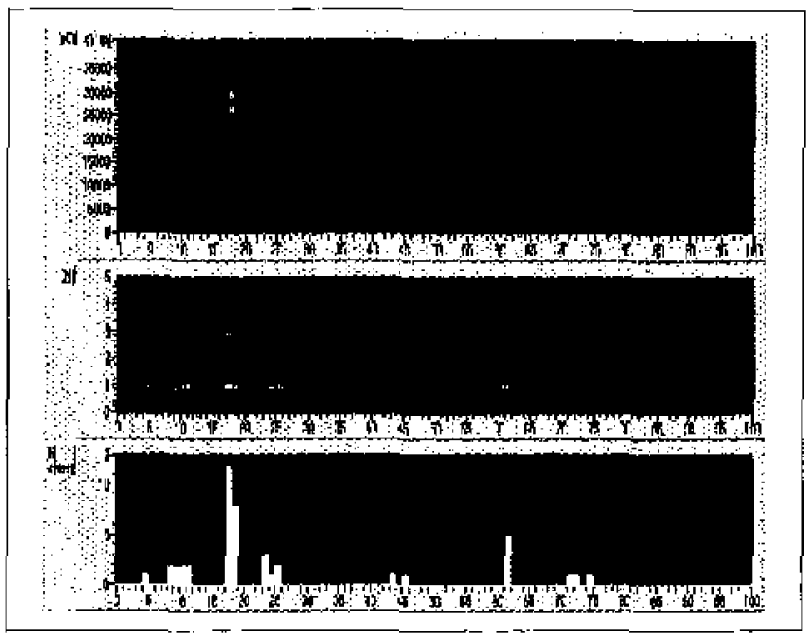

Tig. 9 Example of statistical evatuation oblained after oschlating

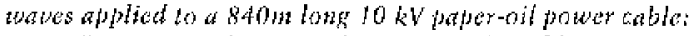
top $=P D$ ragnitudes persws location in tha cable middle r. Plo intensily versts lacation in the cable botton $=$ PD intensity $(5 \mathrm{~m}$ classes) werss location in the cable

the oscillating phase of the test cycle the DC power supply is discontected to provide sensitive P'D measurement (ligg. 7).

Since the oscillating freguency represents the AC conditions of the power line frequency, the measurement bandwidth if the PD circuit has becn chosen in accordanee with IEC 60270 recommendations. For the purpose of location by travelling waves, the bandwidth is increased up to 10 $\mathrm{MH}$ (Fig. 8). In combination with a $100 \mathrm{MH} \%$ digitizer and depending upon cable type-e.g., XI,Pti or paper-oil-the detection and location of PD pulses remains sernsitive for $\mathrm{Ca}$ ble length of few kilometers.

\section{PD Evaluation}

The PD signals, which are ignited during one or morc oscillating waves and are detecred by the system, can be processed for two purposes.

First, each of the PD pulses catn be analyzed for reflections using travelling wave anajysis (Fig. 9). Statistical cvaluation of $P D$ signals obtained after several oscillating waves can be used to evaluate the location of discharge sites in the power: calle (Hig. 9).

Second, values of capacitance $C$ and tan $\delta$ can be calcu lated based upon the oscillating wave time and frequency characteristics (lïg. 10).

Third, after several oscillating waves the wholc discharge sequence can be resolved into a phast-resolved PI pattern. In this way patterns can be obtained that are similar to those recognized under $50(60) \mathrm{Hz}$ conditions (Fig. 11).

For recognition purposes such l'D phase-tesolvod patterns can additionally be processed using statistical discrimination and classification tools $[8,9 \mid$. As a result, $\mathrm{PD}$ datalyases with reference to typical degradation examples in calbles or cable accessories can be created for maintenance purposes [10]. 


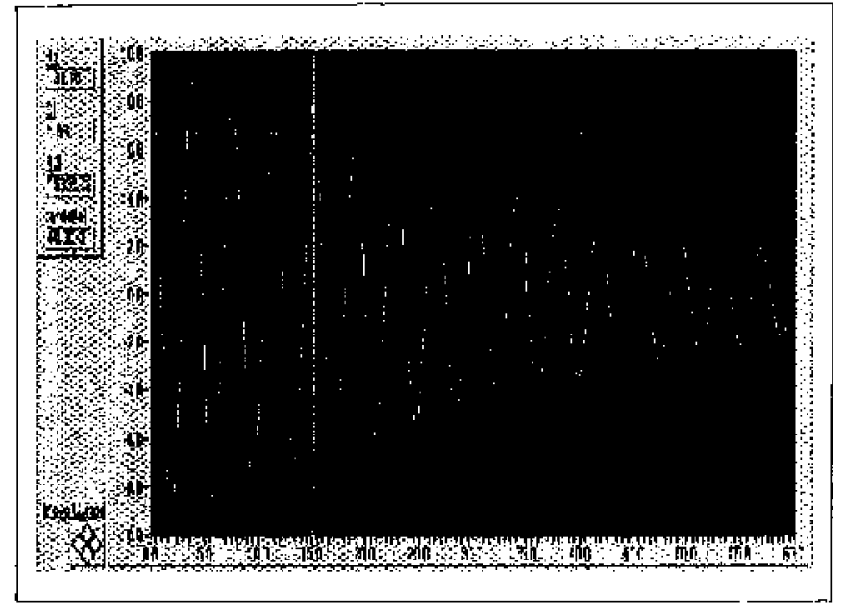

Fig. 10 Franple of calculation of $C$ and tan 8 un the basis of osellating wave time

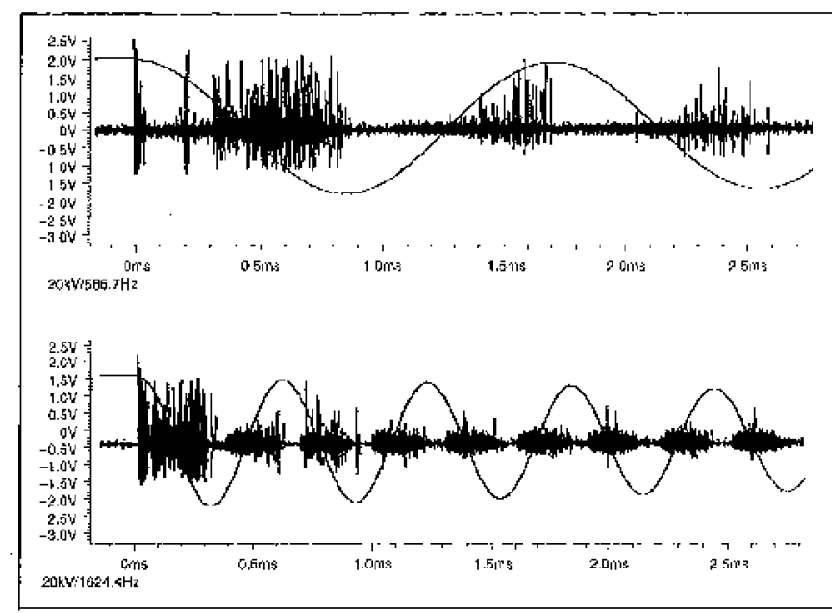

Fig. 11 Comparison of phase-resolved PD patterns obtaincd by OWTS for the same internal defects for two difforent wave frequencies

\section{Comparison to $50 \mathrm{~Hz}$ AC Energizing Method}

Evaluating insulation condition of a cable section on the based of the $\mathrm{PD}$ activity, several aspects are of inportance $[11,12]$. Anong others, the evaluation of $\mathrm{PD}$ inception voltages as well as the measurable PD amplitudes and finally the phase-resolved PD patterns are important by analysis of discharging site in a cable section.

To prove that PD phenomena (inception condition, PD level) as observed at oscillating wave voltage stress ate truly representative of a $50 / 60 \mathrm{~Hz}$ wave applied voltage, several on-site tests have been performed in the past, where the cable samples are stressed with $50 \mathrm{~Hz}$ ac voltages and oscillating wave voltages, In the following impottant results of these investigations are presented.

\section{PD Inception Voltage and PD Magnitude}

Labotatory experiments have been performed to provide insight into the inception conditions and measurable PD anplitude [7|. A series of PD measurements were performed on

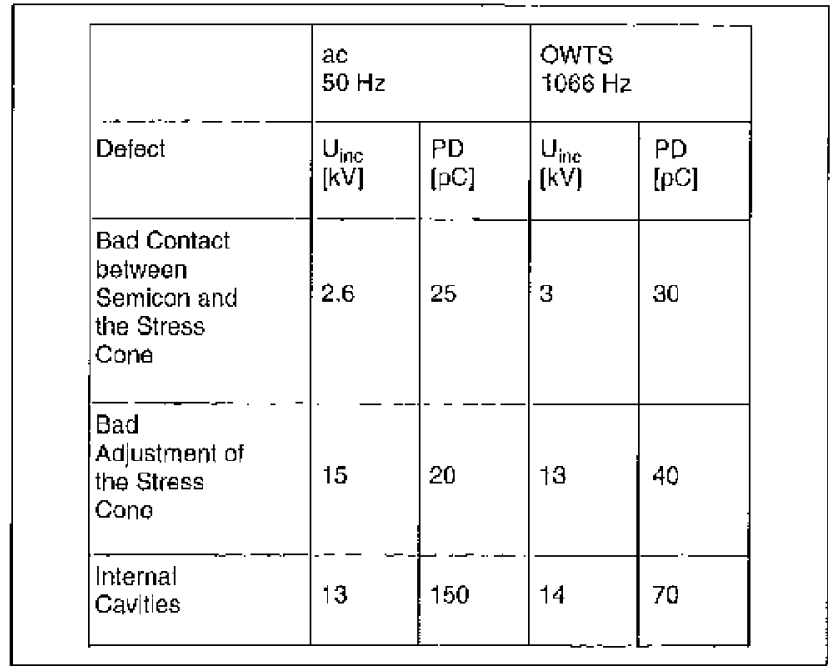

7ig. 12 Comparison of PD magnitudes and inception wolleges olnained for the same internal dofects in cable accessories by different charging voltages: $50 \mathrm{~Hz}(\mathrm{ac})$ power frequency and oscillating wave woltages of $1066 \mathrm{~Hz}$

\begin{tabular}{|cc|l|l|}
\hline \multicolumn{2}{|c|}{ Test voltago } & $\begin{array}{l}20 \\
50 \mathrm{~Hz}\end{array}$ & $\begin{array}{l}\text { OWTS } \\
\mathbf{2 2 0} \mathrm{Hz}\end{array}$ \\
\hline $12 \mathrm{kV}$ & (A) & $450 \mathrm{pC}$ & $500 \mathrm{pC}$ \\
& (B) & $970 \mathrm{pC}$ & $450 \mathrm{pC}$ \\
& (C) & $500 \mathrm{pC}$ & $650 \mathrm{pC}$ \\
\hline $16 \mathrm{kV}$ & (A) & $350 \mathrm{pC}$ & $950 \mathrm{pC}$ \\
& (B) & $700 \mathrm{pC}$ & $850 \mathrm{pC}$ \\
& (C) & $770 \mathrm{pC}$ & $900 \mathrm{pC}$ \\
\hline
\end{tabular}

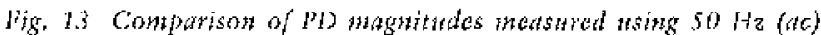
power frequency, and oscillating wave voltages of $220 \mathrm{IJz}$ applied on three $3235 \mathrm{~m}$ long $50 \mathrm{kV}$ mass power cables: (A). (B), and (C) at $12 \mathrm{kV}$ and $16 \mathrm{kV}$ iwo voltage levels

realistic internal defects made in $6 \mathrm{kV}$ plastic insulated cable accessories. In particular, the same samples have been energized with initially $50 \mathrm{~Hz}$ and then again using $1066 \mathrm{H} /$ oscillating wave volrages. In Fig. 12, results of inception voltages and neasurable in lpC]/[nC] PD levels are summarized.

[n Hig. 13, a comparison of PD matuitudes measured at two voltage levels on three cable samples is shown. Using both methods, the inception of discharges was detected at the following voltages: sample $(\Lambda): 6 \mathrm{kV}$; sample $(B): 3 \mathrm{kV}$; sample (C): $5 \mathrm{kV}$.

It follows from these fignres that in comparison with 50 $\mathrm{Hz}$ (ac) the PD level as well as the PD inception voltages are in the same range. As a result, taking into account the stochastic behavior of internal discharges no significant difference has been observed.

\section{PD Location Mapping}

It is known that a locil presence of discharges in a cable section or in cable accessories indicates possible defecr, e.g., mounting defect, local insulation degradation. Therefore, in 


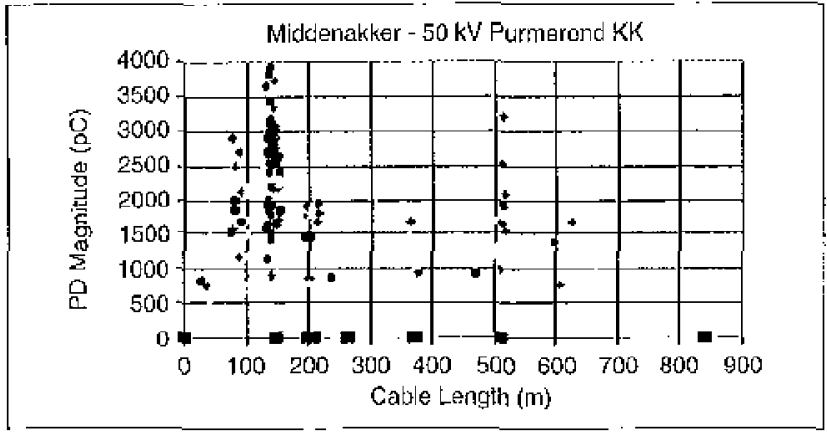

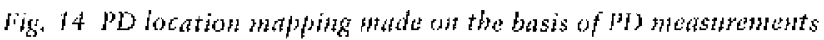
thing oscillating wave charging (25 times) of a $840 \mathrm{~m}$ hong, 17 -year-old $10 \mathrm{kV}$ paperioil prewer cable

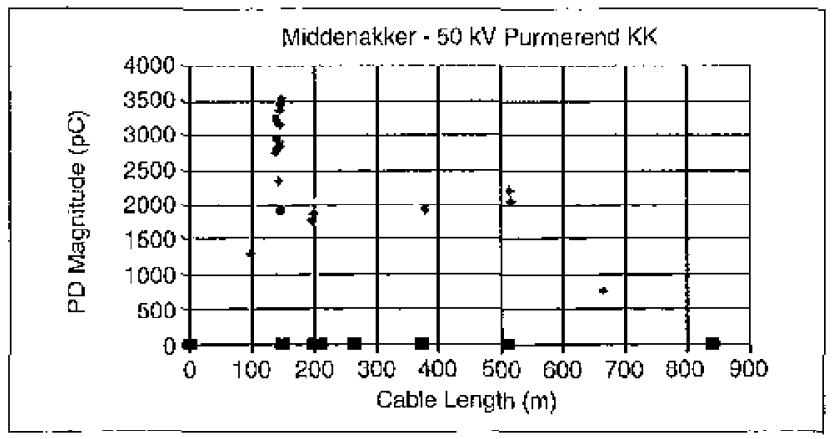

Fig. 15 Po location maphing mate ow the basis of Pl) measterentents wing $50 \mathrm{~Hz}$ ac onergizing (1.5 minntes) of a $840 \mathrm{~m} / \mathrm{hng}$, 17 -year-old 10 kV poperiofi prower cable

Table I. Measuring Resulls from Three 10 kV Paper/Oil Power Sections

\begin{tabular}{|c|c|c|c|c|}
\hline & \multirow{2}{*}{$\begin{array}{l}\text { Voltage } \\
\text { [kV] }\end{array}$} & \multicolumn{3}{|c|}{ Measured PD [pC] } \\
\hline & & Cable a & Cable b & Cable c \\
\hline \multirow{3}{*}{ Phased U } & $0.3 \mathrm{U}_{0}$ & & . & 1500 \\
\hline & $0.5 \mathrm{U}_{0}$ & 1400 & 2500 & 3500 \\
\hline & $U_{0}$ & 2900 & 2900 & 4009 \\
\hline \multirow{3}{*}{ Phase v } & $0.3 \mathrm{U}_{0}$ & - & - & 1500 \\
\hline & $0.5 \mathrm{U}_{0}$ & 1400 & 2500 & 3500 \\
\hline & $U_{0}$ & 3000 & 3000 & 4500 \\
\hline \multirow{3}{*}{ Phase W } & $0.3 \mathrm{U}_{0}$ & - & - & 1700 \\
\hline & $0.5 \mathrm{U}_{0}$ & 1600 & 25010 & 3300 \\
\hline & $\mathrm{U}_{0}$ & 2900 & 30,30 & 4100 \\
\hline
\end{tabular}

the case that the PD inception voltage, the detectable PD magnitudes as well as phase-resolved PD patterns can be a symptom for deviation of insulation conditions of a particular cable section, sensitive location of discharging sites is important. For this purpose as mentioned in the previons text, several PDD pulses are analyzed as travelling waves for their reflections. As a result a PD location mapping can be made, showing the PD anplintes or intensity in function of the cable length and the location of cable accessorics (Figs. 14 and 15).

In Figs. 14 and 15, PD location mappings are shown, which have been obtained nsing both methods applied to the sance $840 \mathrm{~m}$ - Jong $10 \mathrm{kV}$ calle section, It follows from these figures that, tsing both unethods, the sane discharge sites are ignited producing similar PD magnitudes. In particular, both the ac $50 \mathrm{~Hz}$ energizing an well as the oscillating wave charging indicates in the joint looated at $150 \mathrm{mP} \mathrm{P}$ dischange activity of $4000 \mathrm{pC}$, which is much highter that clsewhere int the cable section.

Unless in this particular joint a deviating P] behavior has been found, to judge the serioustess of the source of these discharges for the insulation condition of this particular cable, further invesrigation of alischarging defects in these type of accessories is necessary.

\section{Field Experiences}

Bascd on three examples from field measurements several relevant aspects related to P'D diagnostics of medirm-voltage power cables are discussed here $[12,13]$.

\section{Different Insulation Conditions}

Measurements discussed in this example are performed on three $10 \mathrm{kV}$ pilper/oil power cable sections:

- 3-core $240 \mathrm{~mm}^{2} \mathrm{Al}$ calle section of $840 \mathrm{~m}$, dating from 1982

- 3-core $95 \mathrm{~mm}^{2}$ Cu cable section of $775 \mathrm{~m}$, dating from 1963

- 3-cote $240 \mathrm{~mm}^{2}$ Al calble section of $4823 \mathrm{~m}$, dating from 1993.

The PD measurement results from the there cable sections are reflected in Table 3. 'I his comparison of $P$ D inception conditions and PJ amplitudes shows that in each of the catle sections different processes occur:

- unless at Un callies a and b show the same P'D magnitudes, at $1 / 2 \mathrm{U}_{0}$ cable b shows much higher P'J than cable a;

- calle c sliows in comparison to cables a and b it all voltages much higher PD magnitudes.

This small comparison may indicate that unless negligible differences in P'D magnitudes as observed at $l_{0}$ various degradation processes are going on in all the three cable sections. ligure 16 shows the PD mappings as made for all three cables inyestigated. The mappings are obtained from several Fl) measurements at oscillating voltages up to $2 \mathrm{U}_{0}$.

According to [14], the use of higher frequencies at $2^{*} \mathrm{U}_{0}$ should not inlituence the destructiveness of the test procedure than at $50 / 60 \mathrm{Iiz}$ ace energizing method. On the contrary, it has been shown in $[14,1.5]$ that the breakdown at oscillating voltages are up to two times higher compared to $50 / 60 \mathrm{H} \%$

The upper cvaluation clearly shows PD activity on differcht joints (black squares) of a cable section. lior example, there is a concentration of $\mathrm{PD}$ at the calls joint of $150 \mathrm{~m}$ from the measuting place, with amplitudes up to $4000 \mathrm{pC}$ in all three phases. The calle joint at $500 \mathrm{~m}$ shows a PD concentration with PD amplitudes up to $3500 \mathrm{pC}$, but mainly in the red phises.

The second oval 1 ation shows that PD concentrations can also oceur on a location between two joints, in the paper/oil 


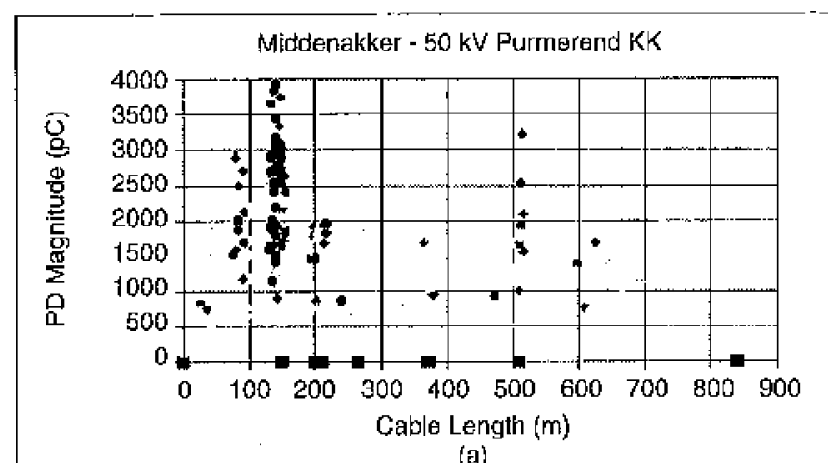

(a)

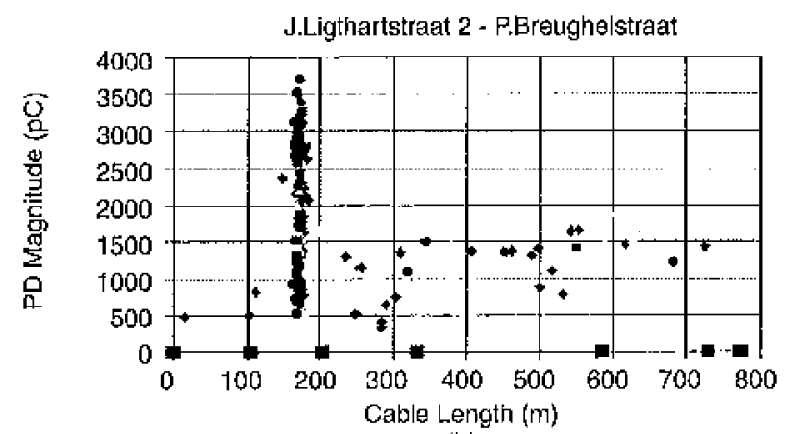

(b)

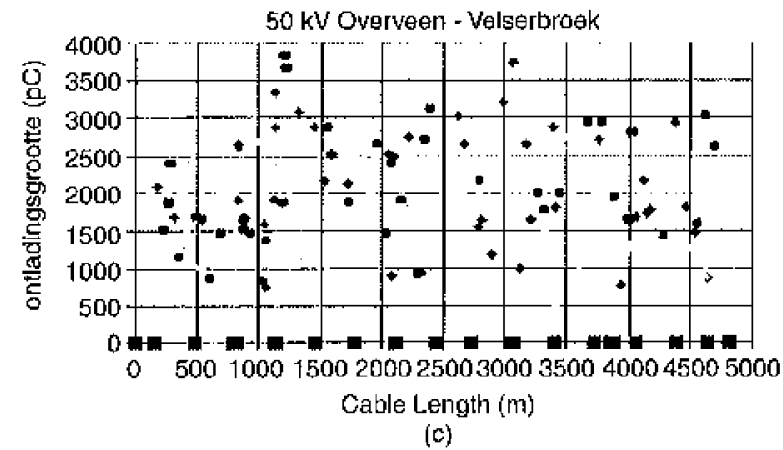

Fig. 16 PD mapping from measurements on three $10 \mathrm{kV}$ paper oil power cables (black squares are the locations of the cabio joints): a) $\mathrm{Pl}$ concentration localed on the cable joints

b) PD concentration in cable instation

c) no clea PD concentration

cable insulation. In this case, a clear concentration of PD is located at $175 \mathrm{~m}$ from the neasuring place, between the cable joints at 105 and $200 \mathrm{~m}$. The network documentation reveals that at this location, the cable runs through a pipeline nnder a motorway.

The third PD mapping of $\Gamma$ ig. 16 shows that a clear concentration of PD in the cable section is not always the casc. A number of $P D$ pulses is measured in the three phases, but they all come from different locations in the cable section.

It follows from the comparison that degradation process of a joint or local damage of cable insulation or even the insulation degradation of the whole cable section shows at $\mathrm{JJ}_{0}$ comparable PD magnitudes, The combination of these val-

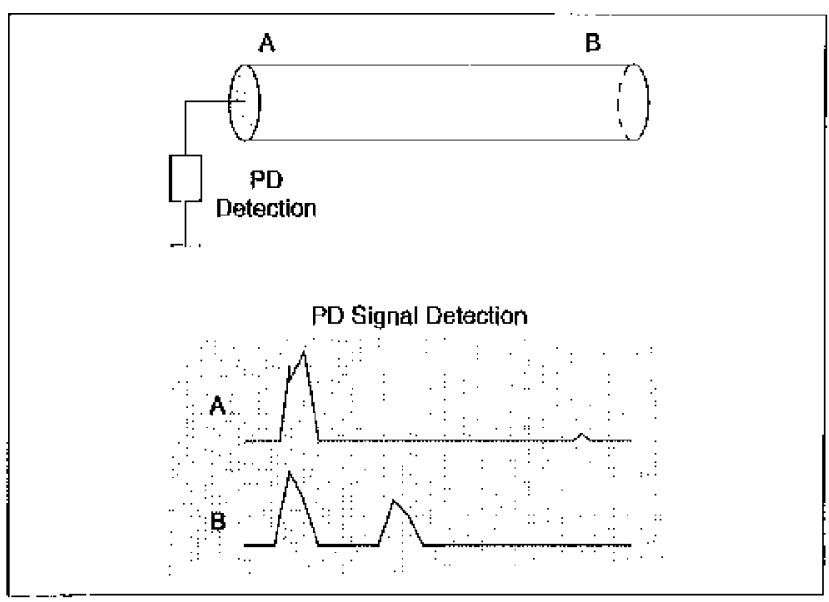

Fig. 17 Whe to the athentation of PD signals, $P D$ pulses from the opposite than the remote side are better deteclable as ibe pulses on the remote side in lons length power cable sections. [IJ located at A give vary small roflections, in contrast to PD located at 1

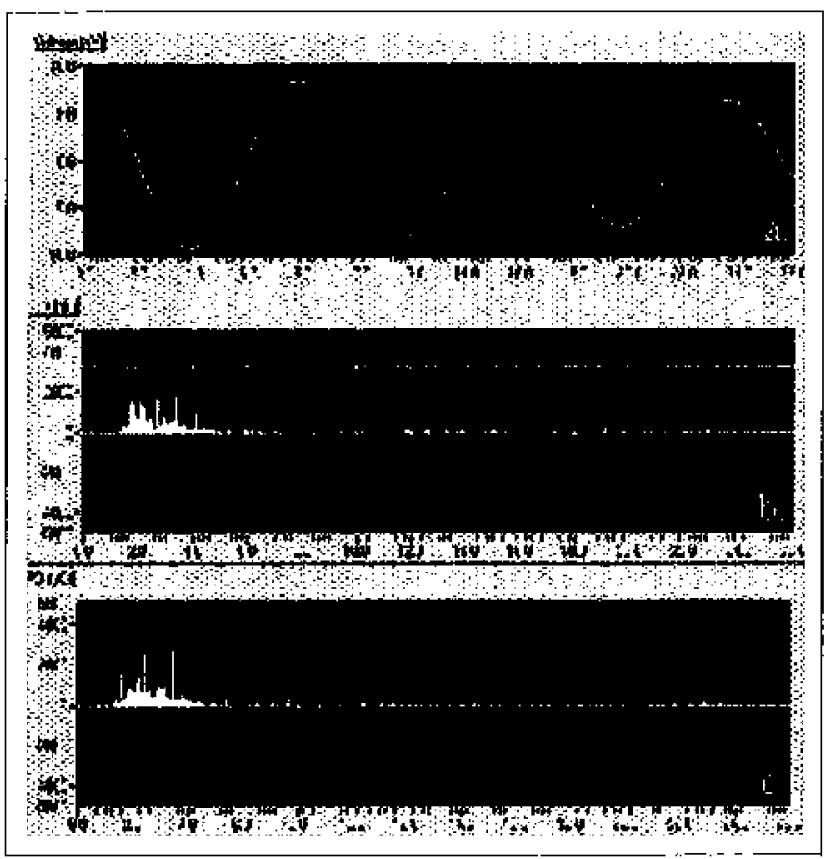

Iig. Is Result from measurements on a $4823 \mathrm{~m}$ long to $\mathrm{kV}$ paperioil potwar cable:

a) test volinge of $120 \mathrm{Iz}$

b) Po sigutals measured out $50 \mathrm{kV}$ Overtren side

c) PD pallern measured on Velserbroek side

ues with the PD inception conditions and determination of discharge sites provides additional information for condition evaluation.

Nevertheless, at this noment no statements can be made about the criticality of these defects, but: it is known that POP concentrations are more hanful than discharges in the whole length of the cable without concentrations. To obtain this information more systematic on-site tests are necessary on similar cables as well as laboratory investigation on service aged cable samplos and accessories. 


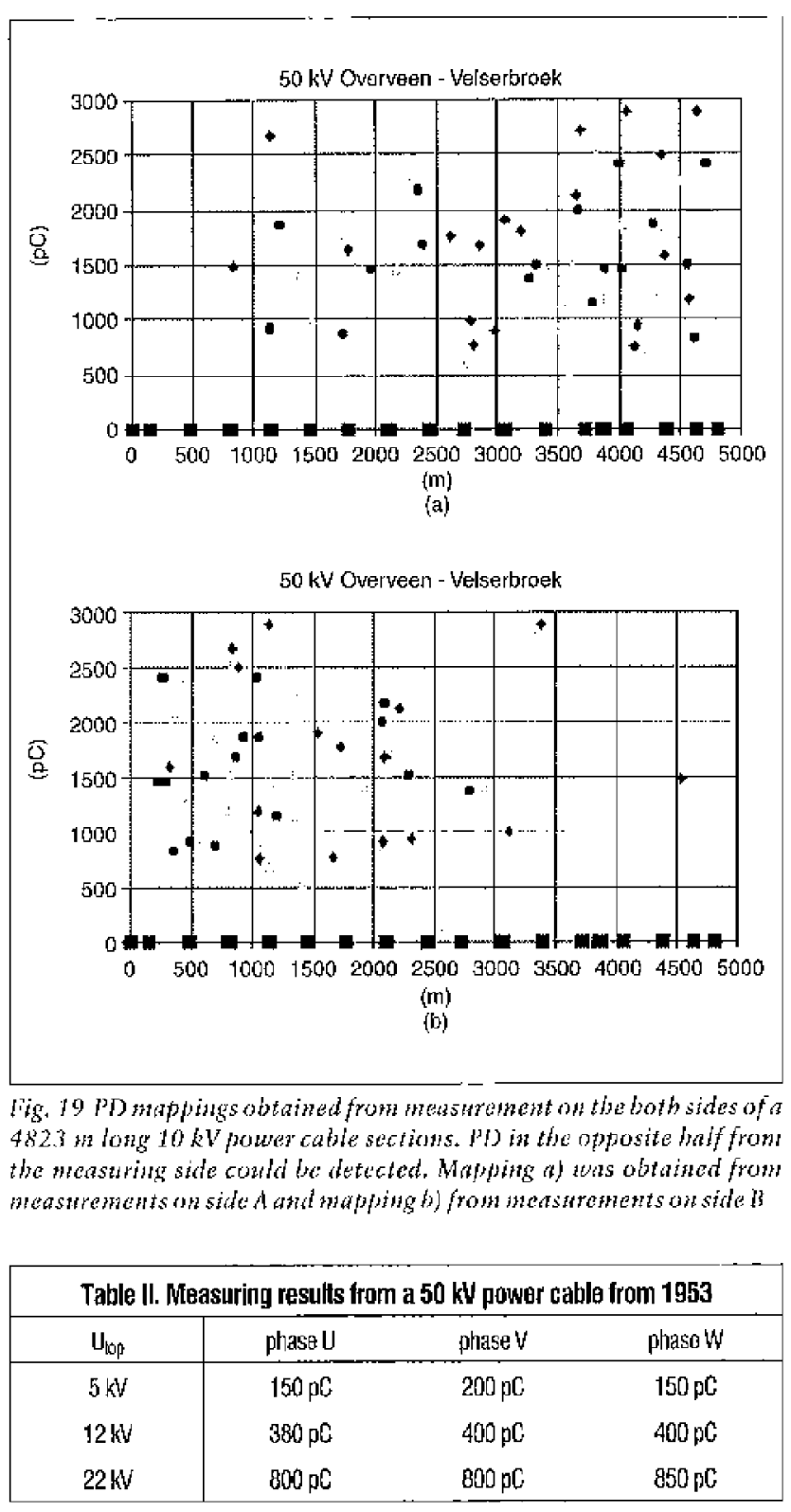

\section{PD Pattern Analysts for Long-Length Cables}

It is known that due to attenuation of PD signals, the detection and location of disclarges in tong-length cables (> $4 \mathrm{~km}$ ) is difficult. In particular, pulses coming fron the opposite of the remote cnd are better detectable than those coming from the remote side (see Fig. 17).

To discuss this problem, measurements are performed on a 3-core $240 \mathrm{~mm}^{2} \mathrm{Al}$ cable section dating from 1993. Total length of this paper/oil cable section is $4823 \mathrm{~m}$. Mcasurements on this cable section are performed on both sides. Higare 18 shows the measurenent tesults from the two sides of the cable section (b and $c$ ) at a test voltage of $9 \mathrm{kV}_{\text {upp }}$ (a.). Inception voltage, PD levels, and PD patterns are similar for both measuring sides.

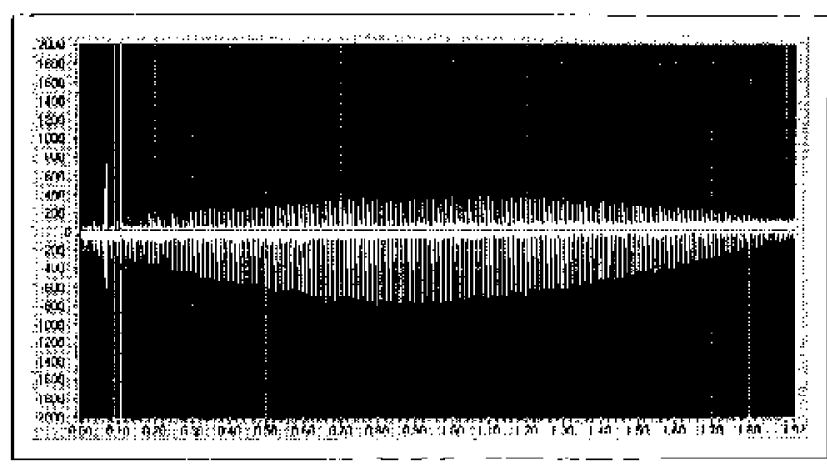

Fig. 20 Sine resembling PD patten in the negative balf of the power froquency cycle, measured on fire $50 \mathrm{kV}$ patemass power cables; tocation of the PD pulses was not possible

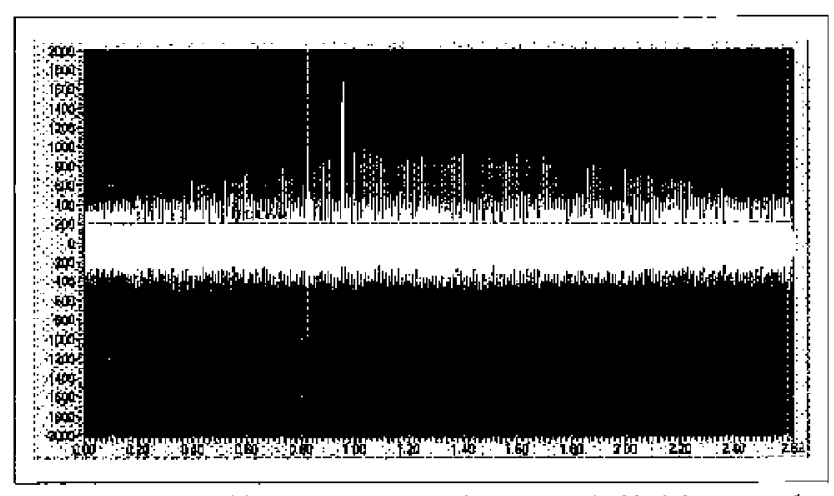

Ijg. 21 sine rescmbling $P D$ pattern in the positive balf of the power fre

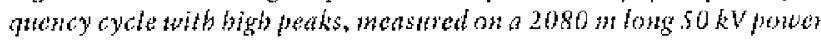
cable. The tocation of the bigh PD signals can be detcrmined

Jocation of the detected PD signals can be made for those pulses originating from $\mathrm{PJ}$ ) sources on the opposite lual of the cable section from the measuring side. Figure 19 a shows the mapping of located PD from the $50 \mathrm{kV}$ Overveen side, the mapping from the Velserbroek side is reflected in Fig. 19 b.

As shown in this example, a combination of PD measurements on buth sides, combined with PD inception voltage, PD magnitudes, and patrerns can support PD diagnostics of long-length power cables.

\section{Location of Discharge sites in Combination whb PD Patterns}

'l'his example handles the measurements performed on six 1 -core $120 \mathrm{~mm}^{2} 50 \mathrm{kV}$ mass power cable, three with a length of $32.35 \mathrm{~m}$, the other three with a length of $2080 \mathrm{~m}$. 'The measuring results from OWTS of one of the cables is reflected in Table II (orher cables show same results). T'he cable was measured with OW'S up to $22 \mathrm{kV}$ top. 'I'he talsle shows a slight growth of PD anplitude as voltages increase.

A notable fact from the performed measurement is that with five of the six cables, 110 particular location of the nneasured PD activities, as shown in cxamples 1 and 2 , could be detcrmined, Figure 20 shows the mensured pD patterns with OWTS from these power cables. "Ihe PD shows a sinc-resembling patrern. 


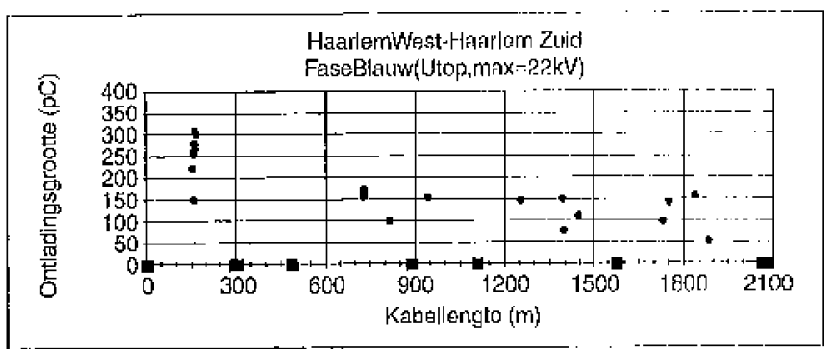

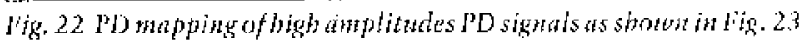

Based on this fact and that PD magnitudes are in the low range the PD activity originates from the total length of the cable, caused by degradation of the insulation material during the 4.5 years of exploitation.

In one of the six measured cables, it was possible to locate the discharges, Figure 21 shows the meaturcd PD pal tern from this power cable. Hese, the sitnc-resembling pattern is visible too, but also high PD signals are towcring above the patterti. Erom these high PD peaks, the location can be determined. $A_{n}$ overview of the located PD is shown in Fig. 22. A concentratton of $\mathrm{PD}$ is located at $15.5 \mathrm{~m}$ fron the measuring side.

\section{Summary}

- Stressing cables with oscillating waves provides gnition conditions for partial discluages that are simular tor $50 \mathrm{~Hz}$ AC energizing conditions, In this way the ['] inception voltage, PD maguitudes as well as the phase-resolved PI) patterns are representative for discharging defects. More. over, based on the traveling wave principle particular discharge sites an be traced back. As a result, it can be conduded that OWTS is a practical and convenicnt somtion for on-site PD diagnosis of medium-woltage power call)es.

- With regard to using OWTS as diagnostic tomls for after-laying tests or mainletance purposes of MV onlle nelworks, several aspects ate of importance. Discharges detected in a calsle section can be related to different insulattion conditions:

- discharging in a particulat cable accessory,

- discharge sites in the cable insulation;

- discharging of the cables insulation without particular discharge site.

- 'The detection of discharges in a calle is not sulficient to judge the seriousness of the discharge source for the insilattion condition of a particular cahle or an accessory. For this purpose detailed investigation of discharging deforts in a type of insulation is necessary:

- analysis of PD inception couditions, PD manitudes and phase-resolved $\mathrm{PD}$ patterns;

- ageing and degradation effects in the insulation and their ntanifestiteg by partial discharges.

- Verifying these results on systematic feedbek trom on-site tests, the OWTS method as a compact and nondestructive tool can become an indispensable tool for diagnosis support-and conelition-based maintenance of medium-voltage power cable systems.

\section{Further Research}

lle gon for dectricily utilitics is to obtain a sonsitive determination of the insulation condition of the medium-volage power cable network. To build up a cable diagnostic, a systematic approach is necessury. Therefore, high-risk cable sections in lin network should be identified and PD measurements on these cable sections performed. In particulat three steps should be taken to develop a condition based diagnostics:

1. From the measurements, systematic information should be obtained on typical PD behaviors for different cable sections. "Ihis information contains the inception conditions of the PD (inception voltage, PL maguitude, cable temperature), the phase resolved patteriss of the mensured PD signals, and furthermore the location of the PD in the cable system (cable insulation, cable joints, or cable terminations).

2. Lvaluation of inportant degradation processes in service of power calses slould be nude by identification of relevant paraneters to indicate the condition of the cable. By developing a database, evaluations of the systematic measurements are simplificd.

3. Finally, the implementation of diagnostics and knowledge rulcs for different itsulation materials (cable insulation, accessorics) should be noade and the application in the ficed checked.

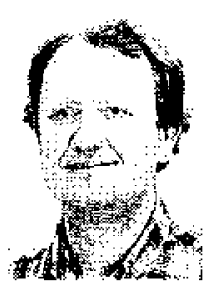

Fdward Gulski was born it 1958 in Poland, In 1982 lo received his Masters degree in Information Technology from the Dreselen University of 'Techunology in Germany, and from 1982 through 1986 he was a rescarch assistant in the HV laboratory there.

In 1987 he begatn rescarch in the partial discharge diagnostics ficld, telocatiug to the Netherlands' Delft University I IV I abonatory. In 1991 he received his Ph. D. degree from Delfi University of 'T tochology. $A$ present, he is an associnte professor involved in education and resenrch in the ficld of mulation diagnosis of $\mathrm{HV}$ components. $\mathrm{He}$ is a member of different CICTRE working groups and task forces.

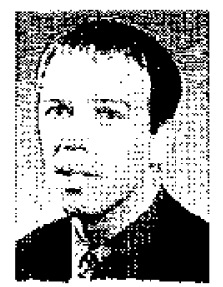

Frank J. Wester was lrom in 1972 in the Netherlands. In 1998 he recoived his M.S, in electrical enginecring at Delfs University of "l'celnology in the field of advanced on-line diagnostics on GIS. Since 1998 he was enployed at NUON CINW in Amsterdan, the Nethertands, as a diagnostic engineer. $\mathrm{He}$ is also wotkitus toward a Ph. D, in the field of ol-site diagnostics for condition-based maintemance of nedium-woltage power able netwonks at the HV Laboratory at the Delfir I Iniversity of 'lectmology.

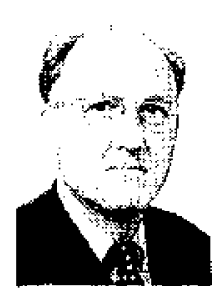

Johan J. Smit was born in 1949 in the Nethorlands. [n 1974 he received his Master's thesis degree in experimental physics at the University of Amsterdam, and in 1979 he received his P1. D. at the State University of Leiden for his resench in magnetism on behalf of the National Science fondation. He was employed for 17 years at KFMA in Atrliem, where he beame section manager within the transmission and distribution com- 
pany. Since 1996 he has been a profexsor in high-woltage technology at the Delft University of lechology. Cumbently his specilie

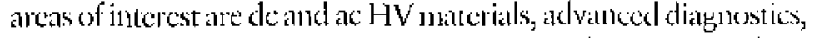
aud maintenatice support systems. Ife is a member of the Thelu ical Commitee of IEC '98 on Hilectrical fosulation Systems. In 1993 tic bcame secrotary of Cigre Study conmitcee 14, Matertils for Technology, of which he is now chatrman,

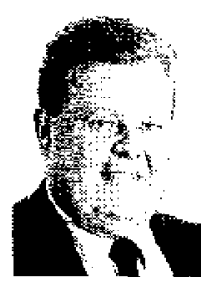

Paul N. Scitr, was born in $1940 \mathrm{in}$ Switzerland In 1964 he rocoived his B.S. in electrical engineering from the H'T'I of /urich. From 1965 througl 1972 he worked in the U.S, stumiconductor industry, at 'l'ansitron and Filicehild, designing integrated circonit test systems.

ln 1972 he co-founded, with ofther engineers, Quantor Corp. and worked as senior designe en-

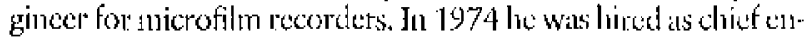
gineer at 'l'ettex lustruments, designing parcial discharge alld an delta test equipument, [11 1983 lo joined r-IAtitELY in Bisel and headed the electronic department in charge of the design of partial discharge, imponse, and and dela test systemis. In 1993 he started bis own company, SEIT7. [nstruments $\Lambda$ i, and prosently designs and thamulactures instruments for the high-voltage field.

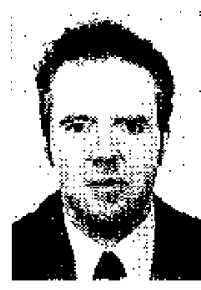

Mark Turner was bom in 1962 in tingtand. I-le recened his traning as an clectronics enginecr and avionics rechniciatl with the Royal Air Force and then changed to a sales career in test: instrumentation, atcaining lis first management position in 1988. Areas of focus from 1985 to 1990 included TV and radio usi equipment, oscilloseopes, power supplies, and logic analyzers. 1990 to 1996 was spent in a varicty of differtnt sales and nurketing roles with Robinson lnstuments, a UK manufacturer of partial discluarge detectors, military chart recorders, and uaval switchgear. In 1996 the left the UK to join the 'ettex Division of Haefely Test. AG and is currenty stadying for an executive MBA at St. Ciallen in Switarland.

\section{References}

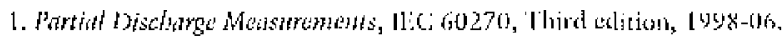

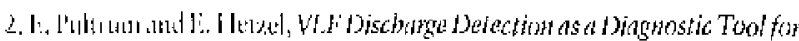
WV Cithls, It:LI: Plis 1997 summer Mecting, 20-24 July 1997, Berlin.

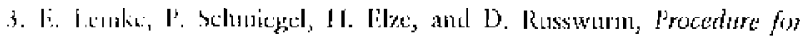

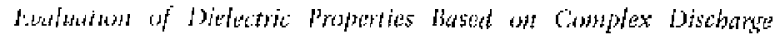

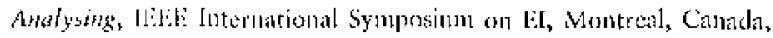
|6-14 Ju|k, 7946.

4. R. Plithl, W. Kalkuer, and I. Krape, Vergleich pen Didguesesystemen zam

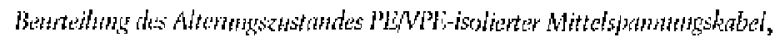

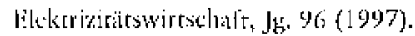

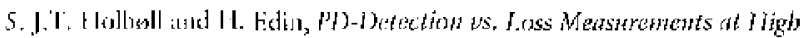

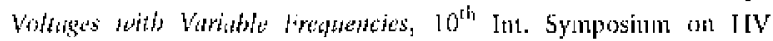

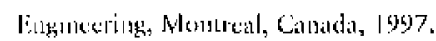

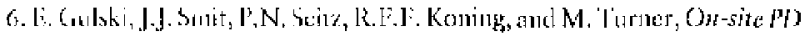

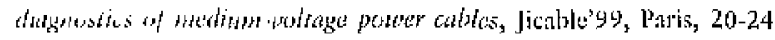
Jurke | yyyt).

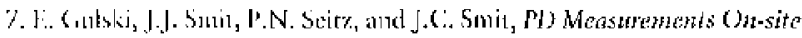

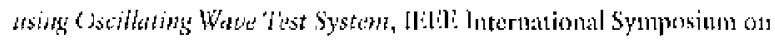
1:], Washiagtom DC: iss, 7-10 June 1998.

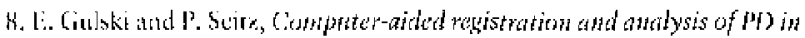

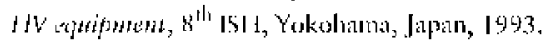

9. L.. Ciulski, H.P'. Burger, A. Zielonka, R. Brooks, Chassification of Defeas

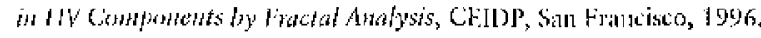

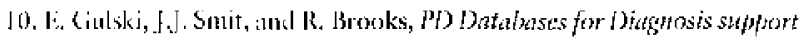

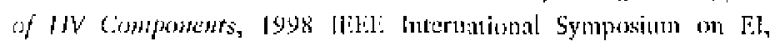
Wistiningl(s)

I I. J. Gulski, J.J. Snit, P.N. Seirz, J.C. Smit, and M. Turner, On-site PD

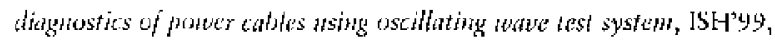

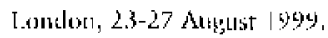

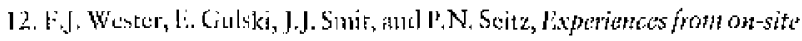

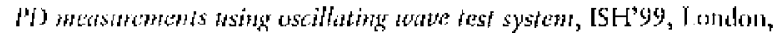
23-27 Alughtse (9y).

13. L.J. Wester, Ii., Grulski, indi J.J. Sinit, Viloctrical and acoustical PD on-site

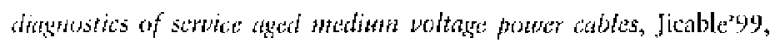
P'aris, 20-24 junc [99y.

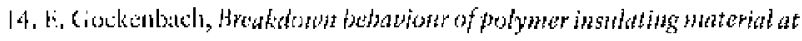
differem freghencis, Heafely LIV Festing \& Diagnostics Stminar '99, Sin Alleonio, y-10 func lygy.

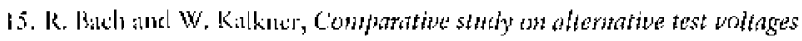

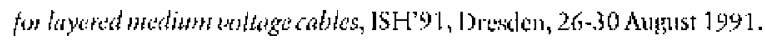

\section{Coaxial 30kV Connectors}

(conlinued from page 11)

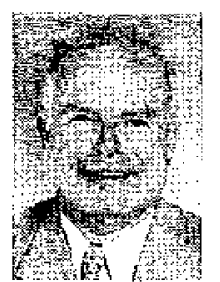

Gerhard H, Schröder has studied telecommunnications ind holds a Pli.D. in ligh-voltage congineering and gas discharge ploysies. He is head of a team that has buile a large part of C.ENN's fast pulsed magnet systems and is now in

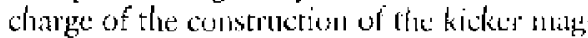
ner systems of the Iarge Hadrun Collider.

\section{References}

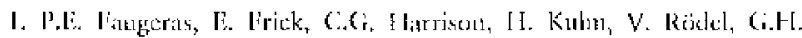

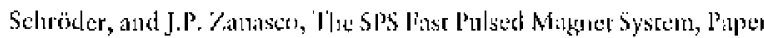
presented at the $12^{\text {th }}$ Modulkir Syungesinum, New York, 1976.
2. F. lirick, II. Kúton, M. Wayer, V. Rödel, Gi.H. Schröbler, and t.

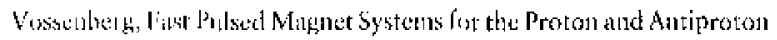

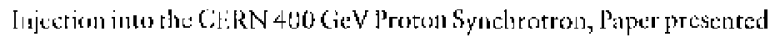

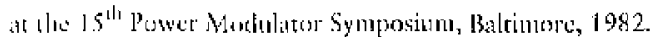

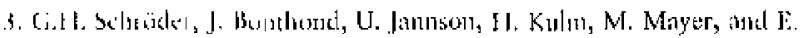

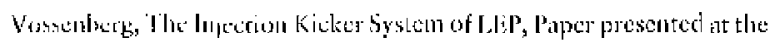

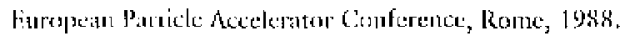

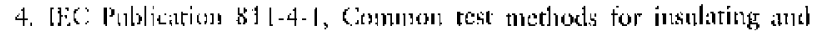

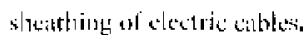

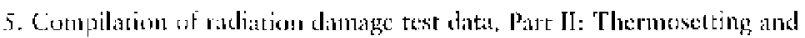

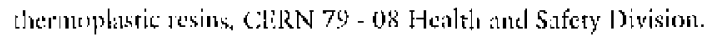

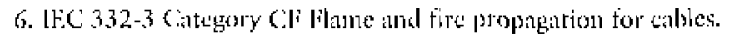

